Dijana Husaković ${ }^{1}$

Anida Šabanović ${ }^{2}$

\title{
THE EFFECT OF BOSNIAN AND HERZEGOVINIAN NATIONAL CULTURE ON CONFLICT RESOLUTION STYLES IN FOREIGN-OWNED COMPANIES
}

\begin{abstract}
Conflicts are an integral part of doing business and companies cannot avoid them. In a globalized and dynamic environment, there is a need to manage conflicts that occur within the company, in a productive and effective way. Conflict management styles are influenced by a number of factors, including the national culture of employees, who will have certain preferences in resolving conflicts in accordance with their culture.

When it comes to multicultural environment, the knowledge of the national culture of the country in which the business is being done, as well as the company's home country, national culture is extremely important for conflict management and creation of positive atmosphere in the company. Doing business in a foreign market additionally complicates the process of the creation of interpersonal conflicts. Thus, top management coming from the home country has a big task of understanding the values and customs which are the part of personality of each employee from another country, and at the same time, the understanding of the national culture of the country in which the business was internationalized.

The aim of the research is to, based on theoretical and empirical research, examine the impact of Bosnian and Herzegovinian national culture on conflict resolution styles used in foreign companies doing business in Bosnia and Herzegovina.

Research results show that the national culture is a significant factor in conflict management in a company, but also in conflicts in general. The level of harmonization of chosen styles and ways of managing them with the national culture of the employees will affect their business performance, positive atmosphere and communication, and more efficiency for achieving the company's business goals.
\end{abstract}

Key words: culture, conflict, conflict resolution styles

JEL: $M 14, M 54, F 23$

1 Associate professor, Faculty of Economics University of Zenica, e-mail: dijana.husakovic@ef.unze.ba 2 Master of Economics, Director of the Foreign Policy Initiative BH e-mail: anida.sabanovic@hotmail.com 


\section{INTRODUCTION}

The influence of national culture on conflict management became a popular subject of research during the 1980s and 1990s, and this interest is not diminishing even today. Research in this area aims to determine the relationships between the dimensions of national culture as independent variables and different managerial concepts, techniques or methods, as dependent variables. It starts from two key assumptions: 1) management theory and practice are a manifestation of the cultural values of the community that created them and have limited value when transferred to a different cultural environment than the one in which they originated; 2) the consistency of managerial practice with the cultural assumptions and values of the community where they are conducted leads to greater efficiency and better performance (Hofstede 2001; Schneider and Barsoux 1997).

Knowledge of the national culture of the country in which company operates, as well as the national culture of the country where the company is established, is extremely important for conflict management and the creation of positive work environment in the company. The most important and comprehensive study of how values in the workplace are influenced by culture was conducted by Hofstede (2001) who defines culture as "the collective programming of the mind distinguishing the members of one group or category of people from others". The phrase "mental programming" is not interpreted literally that people are programmed in the same way as computers. It means that an individual possesses certain patterns of thought, feeling, and potential action learned during life, and much of these patterns, values, and norms are learned and accepted in early childhood, when an individual goes through a period of primary socialization in the family as well as in the school, where he or she is learning patterns of their culture or culture of its society, and adapts to the same.

Hofstede (2001) singled out six dimensions, namely: Power Distance, Uncertainty Avoidance, Individualism versus Collectivism, Masculinity versus Femininity, Long-Term Orientation versus Short-Term Orientation and Indulgence. These dimensions are used to describe culture so that they can be compared, explored and known better. They do not encompass all parts of complex systems cultures, but they provide good foundation. This is of a high importance for managers seeking to internationalize their companies in foreign countries and manage day to day operations given the growing diversity in workforce, customers and other stakeholders as well as for high impact culture has on different parts of doing business, including conflict management. Robbins (2005) believes that the work environment is one of the places where conflicts most often occur, especially as organizations become less hierarchically organized and more functional. Interdependence and cooperation between employees, as well as between different departments or levels, which have different 
interests and views are becoming increasingly important in the organization, and that means that greater opportunities for conflict can happen.

Given the growing number of companies with foreign capital and owners in Bosnia and Herzegovina as well as scarce of research in this area, it seems justified and necessary to address and examine the question of the impact of culture of Bosnia and Herzegovina on conflict resolution in foreign-owned companies doing business in Bosnia and Herzegovina.

\section{Literature Review and the Theoretical Framework of the Research}

\subsection{Conflict management}

The term "conflict" can be defined differently. The simplest definition implies that conflicts are a part of the life as well as of any change with the possibility of transformation into a source of energy, which gives the possibility to manage them in a constructive way (Hammerich 1996, p.12). According to Mandić (2003, p. 33), conflicts in a group can arise due to the status of one group, based on origin, economic power, personal abilities and achievements and the group itself can occupy different status in the society. Interpersonal conflicts represent conflicts between individuals. One's beliefs can easily clash with another's, especially if they are contradictory. Someone's motives can easily differ in a given situation, and thus cause conflicts.

Some of the most common sources of conflict are interdependence, inadequate reward system, and insufficient communication. In these situations, the most important thing is conflict management, and the goal is to notice the positive sides of the conflict and ultimately achieve a positive outcome. Sources of conflict can be different, and most often economic, ideological, political, personal, due to the nature of work, external factors, different needs and desires, job satisfaction / dissatisfaction, etc. According to Sikavica (2011), the emergence of conflict is conditioned by the existence of a cause. The causes of conflict are numerous and diverse, and the basic causes of conflict arise from the definition of conflict. The first refers to the existence of at least two parties, the parties may be individuals or groups and the third cause is the conflicting interests of the conflicting parties. The immediate cause of conflict is the stratification of various needs, aspirations, motives, desires, and interests of the conflicting parties. 
Figure 2.1: Causes of conflict

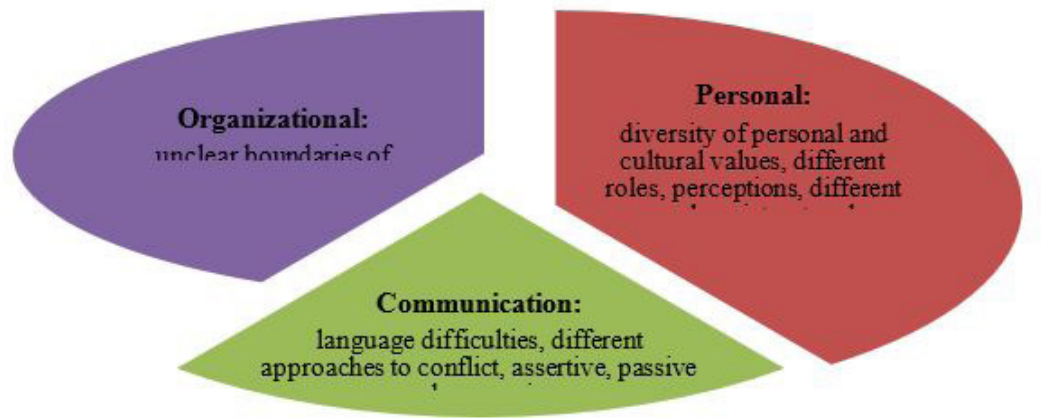

Source: Author according to Rijavec and Miljković 2002, p. 13-15

In companies, two types of conflicts are most often distinguished, and these are: structural and personal conflicts. The first type of conflict implies a situation where there is a disagreement with the goals to be achieved and the way in which those goals are planned to be achieved. The second, on the other hand, is emotional and occurs when two or more people simply cannot agree and organize to work together and perform tasks. Personal conflicts are dysfunctional and should be reduced to the lowest possible level. (Rijavec and Miljković; 2002, p. 3)

Table 2.1: Types of conflicts

\begin{tabular}{|l|l|l|l|l|}
\hline $\begin{array}{l}\text { Considering the } \\
\text { consequences }\end{array}$ & $\begin{array}{l}\text { Considering the } \\
\text { subject }\end{array}$ & $\begin{array}{l}\text { Considering the } \\
\text { costs }\end{array}$ & $\begin{array}{l}\text { Considering the } \\
\text { participants }\end{array}$ & $\begin{array}{l}\text { Considering the } \\
\text { organizational } \\
\text { level }\end{array}$ \\
\hline $\begin{array}{l}\text { Functional and } \\
\text { dysfunctional } \\
\text { conflicts }\end{array}$ & $\begin{array}{l}\text { Cognitive and } \\
\text { affective conflicts }\end{array}$ & $\begin{array}{l}\text { Cheap and } \\
\text { expensive } \\
\text { conflicts }\end{array}$ & $\begin{array}{l}\text { Individuals, } \\
\text { groups or entire } \\
\text { organizations }\end{array}$ & $\begin{array}{l}\text { Horizontal and } \\
\text { vertical conflicts }\end{array}$ \\
\hline
\end{tabular}

Source: Sikavica; 2011.p. 772

The focus of conflict management is not solving the conflict, but managing the conflict. The management of different types of organizational conflict includes the following: (Rahim 1992, p. 38)

- Intrapersonal conflict management includes aligning individual goals and expected roles at work with employee needs and responsibilities to optimize the achievement of individual and organizational goals;

- Interpersonal conflict management involves training of the members of the organization with the aim to learn five styles of conflict behaviour, so they can use the appropriate style in different situations;

- Conflict management within a group includes learning a largely integrative style of behaviour with other members of the organization, so that their energy, expertise, and resources are channelled towards creating and/or achieving group goals; 
- When it comes to the conflict between two or more groups, conflict management includes mainly learning of the integrative style, so that the energy, expertise and resources of members of conflicting groups are directed towards synergetic solutions to common problems or the achievement of organizational goals.

Conflicts that are ignored and unresolved cause emotional discomfort, and can often escalate to large proportions. If it "confronts" the conflicts that have arisen, then the possibility of new ones is reduced or their resolution will be easier in the future. Managers should use indirect techniques first and then direct conflict resolution techniques. Indirect techniques include reducing contact between the parties to a conflict, appealing to common goals, transferring responsibility for resolving conflicts to a higher level, and reorganizing. The simplest indirect technique is to reduce contacts between the parties who are in the conflict situation, whether it is individuals or groups in conflict. For example, moving to another room, not attending the same meetings, etc. Conflict relents over time if people do not meet a lot because they have nothing to negotiate and agree about (Rijavec and Miljković 2002, p. 23).

Table 5: Selection of the best technique depending on the situation

\section{BIDDING}

A critical situation requires quick and decisive action. A situation in which some unwanted decision needs to be implemented. The conflicting party is sure that he/she has the right point, and the situation is very important for the well-being of the organization. Bidding is a good strategy against a conflicting party that wants to benefit from its incompetent behaviour.

\section{COOPERATION}

Cooperation is the best when issues are very important to compromise and when time is not limited. Insight into different opinions. The desire for everyone to accept the decision to make its implementation more efficient. The goal is to improve working relationships.

\section{COMPROMISE}

Compromise is the best when goals are important and the use of other means would have negative consequences. The conflicting parties are equally powerful and have mutually exclusive goals. A temporary solution to complex issues that cannot be resolved immediately. Assistance in the situation when the cooperation or bidding have failed.

\section{BACKDOWN OR ADJUSTMENT}

Backdown is the best when the conflicting party realizes that he/she has no right. It is the best to be reasonable and listen to a better opinion. For one conflicting party, the existing problem is more important. Preparing support for the future situations. Stability is of particular importance as well as maintaining agreement between the parties.

\section{AVOIDANCE}

Avoidance is the best solution when there are more important problems. A situation in which resolving a conflict would do more harm than good. The problem is just a symptom of another problem. Allowing the conflicting parties to calm down. A situation that others can resolve more successfully.

Source: Rijavec i Miljković, 2002, pp. 38 
One of the three basic strategies suggested to managers and leaders to resolve conflict is Negotiation, which can be applied when the parties who are in conflict have common interests in addition to conflicting interests. Two or more parties enter into negotiations because they can offer something to each other and get something in return. Disagreement or conflict causes a different view of the conflicting parties about what they give and what they want to get. Resolving such a situation depends on the choice of the strategy or of the skills of the negotiator. Negotiation strategies are distributive and integrative negotiation.

According to Gibson, Ivancevich and Donnelly (1985, p. 62), other two very important strategies are The strategy of the superior goal, and the goal of the strategy is to achieve cooperation between the "warring" parties by joining forces to oppose the jointly identified enemy. The idea is that the weight of the common problem and its solution show how negligible personal interests are. And third, The strategy of third-party intervention, where an external consultant is hired when it is necessary to have a neutral party, although in organizations it is usually the manager. When it comes to this strategy, two tactics are possible: mediation (mediator connects the conflicting parties, explains the problem to them, improves communication between them, offers recommendations and thus creates a way for them to come to a solution to the problem) and arbitration (the arbitrator may impose a certain solution to the conflicting parties).

\subsection{Cultural dimensions of the international business environment and its implications for conflict resolution styles}

National culture is one of the sources of organizational culture and also influences other elements of business entities: organizational structure, employee motivation, management leadership style, etc. (Vujić 2012, p. 178). The national culture does not entirely shape organizational culture, but it sets the framework for its activities. National culture also shape behaviour of different stakeholder groups, who influence business performance of company. Within a company, a good manager is one who, regardless of the size of the company and the activity in which the company is engaged, effectively manages diversity by meeting the needs of a group of the employees which have different national cultures and understanding the differences in employee structure with regard to gender, religion, ethnicity and race, nationality, etc. Therefore, understanding the culture and its impact on business performance is of paramount importance for managers, especially in international setting.

During the 70s and 80s of the last century, one of the theories and methodologies for measuring and comparing different national cultures was developed, and it was founded by Geert Hofstede (1980). Together with his associates, Hofstede identified 
the dimensions of national culture. Primarily, he identified four dimensions, which were followed by two additional. The dimensions of national culture, according to Hofstede, are:

- Power Distance (PDI) - this dimension expresses the level to which less powerful members of the society accept and expect inequality in the distribution of power. The fundamental problem is how society handle inequalities among people. People in societies that show a great level of power distance accept a hierarchical order in which everyone has their place and which needs no further explanation. In societies with low PDI, people tend to equalize the distribution of power and seek justification for power inequalities;

- Uncertainty Avoidance (UAI) - expresses the level of anxiety that members of a particular culture feel about insecurity and uncertainty. The fundamental problem discussed here is how society faces the fact that the future cannot be certain: should we try to control the future or simply let it happen? Societies that show strong UAI follow established beliefs and behaviours and are intolerant of unusual behaviours and ideas. While, on the other hand, societies that poorly avoid uncertainty show a more relaxed attitude and uncertainty is valued much more than principles;

- Individualism versus Collectivism (IDV) - individualism in relation to collectivism distinguishes cultures that value more the individual effort of the individual in relation to collective efforts and team results. In collectivist societies, the strength of the group is very pronounced and for the individual the most important thing is to belong to "his" group, which will protect him in exchange for loyalty. The values of the group in which the individual is integrated determine his set of values as an individual, which is less important than the set of values of the collective;

- Masculinity versus Femininity (MAS) - Masculinity society has clearly defined social roles of men and women: men should be assertive, strong and oriented to success in material terms, while women should be more modest, caring and oriented to the quality of life. Femininity denotes a society with overlapping roles of men and women, in which both men and women need to be modest, caring and quality-oriented. Most national cultures with corresponding masculinity / femininity index values are between two extremes;

- Long-Term Orientation (LTO) versus Short-Term Orientation (STO) Long-term time orientation emphasizes the merits oriented to future results, especially perseverance and savings, while short-term time orienta- 
tion emphasizes the merits oriented to past and present such as respecting tradition and fulfilling social obligations.

- Indulgence - This dimension is defined as the extent to which people try to control their desires and impulses, based on the way they were raised. Relatively weak control is called "Indulgence" and relatively strong control is called "Restraint".

Empirical study of the national culture of different countries, including Bosnia and Herzegovina, according to Hofstede's methodology, was conducted in 2005, as stated in Rahimić and Podrug (2013, p. 259).

Graph 2.2: Values of national culture dimensions for Croatia, BiH, Slovenia and Serbia

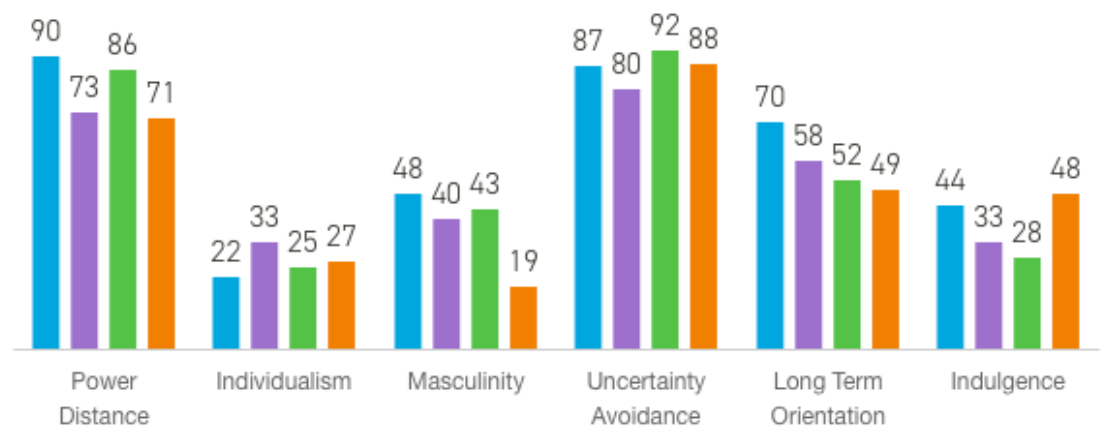

* estimated

Bosnia and Herzegovina* Croatia Serbia Slovenia

Source: Results generate from 6-D Model $($

As presented in Graph 2.2., Bosnia and Herzegovina scores very high on Uncertainty Avoidance dimension, meaning that people do not readily accept change and are very risk-averse, which means that they do not change jobs frequently, prefer working for someone else rather than starting their own business and favour rules, laws, policies, and regulations.

Bosnia and Herzegovina scores high on Power Distance dimension also, which means that people accept that power is distributed unequally in society. Therefore, hierarchy is accepted and respected, people are talked to differently depending on their status in society and privileges are recognized.

Bosnia and Herzegovina is a collectivistic culture in its nature where belonging to groups is very important, starting with extended family, neighbours, friends and 
acquaintances. The more respected group you are member of, the more respected you are regardless of your individual value. It's worth mentioning that newer data shows shift from strongly collectivistic culture towards individualistic culture, which is also the case with $\mathrm{M} / \mathrm{F}$ dimension.

Recent research shows the dominance of the masculinity over femininity dimension, which can be interpreted in the context of the characteristics of the sample, because $56 \%$ of respondents in the empirical study were younger than 30 years. Moreover, for younger people opportunity for advancement, material income, job challenge and others are extremely important, and it all represent masculine values. However, Bosnia and Herzegovina also traditionally represents femininity culture in which taking care of other people is very important as well as quality of life over achievements.

In 2010, Minkov (2011) published data on the long-term/short-term time orientation dimension for a total of 93 countries, where he identified Bosnia and Herzegovina (70) as a country with a more pronounced long-term time orientation, meaning that its culture is pragmatic in nature. Also, as data shows, with an intermediate score of 44, no clear preference between Indulgence and Restraint can be established for Bosnia and Herzegovina.

As world is moving faster towards a global society, borders are becoming less important and managers deal increasingly with different cultures. Given the diversity of global cultures, conflicts will arise inevitably between individuals or organizations. Increased chances of conflict suggest that managers ought to be aware of the conflict resolution styles used by colleagues from other cultures. It could be said that some efforts have been expanded in the area of cross - cultural research in the field of conflict management (e.g. Elsayed - Ekhouly and Buda 1996, Kozan 1989, Rahim and Blum 1994, Tinsley and Brett 2001).

Conflict resolution is the process by which two parties reconcile their goals to the extent that they are mutually consistent (Nicholson, 1975). In other words, conflict resolution styles provide an overall picture of a person's communication orientation towards conflict (Oetzel and Ting - Toomey 2003). Among the studies that address the different styles of conflict resolution the most utilized model is the one that was initially presented by Blake and Mouton (1964). They are generally credited as the first management scholars to recognize the importance of the various styles of conflict management. Parallel strategies have been advanced and further developed by Kilman and Thomas (1975) and Rahim (1983). Since Rahim's model is used in this study as basic model for resolution of cross - cultural conflict situations, some more details are provided.

Rahim (1983) elaborated the Dual concern model that differentiates the styles for handling conflict on two dimensions: the concern for self and the concern for others. 
A combination of the two dimensions results in five specific styles of handling interpersonal conflict, as follows:

- The integrating style involves high concern for self as well as the other party involved in the conflict. It is concerned with collaboration between parties.

- The obliging style involves low concern for self and high concern for others. It involves smoothing over differences and focusing on areas of agreement.

- The dominating style involves a high concern for self and a low concern for the other party involved in the conflict. It has been described as forcing one's viewpoint at the expense of others.

- The avoiding style is associated with low concern for self as well as for the other party. It has been associated with withdrawing from the conflict situation.

- The last style is the compromising style that involves moderate concern for self as well as for the other party involved in the conflict. It is associated with give - and - take or finding middle - ground solution.

Another classification of these styles (Rahim 1992) indicates two alternative dimensions: a distributive dimension which consists of a dominating or an obliging style, and an integrative dimension, that is an integrating or avoiding style of dealing with conflicts. The instrument that Rahim proposes for measuring these styles is Rahim Organizational Conflict Inventory-II (ROCI-II) (Rahim 1983). This instrument consists of 28 statements and was developed specifically to improve the reliability and validity over other conflict - handling measures. The Dual concern model, together with the ROCI-II, is extensively used in the field of cross-cultural conflict management research.

The one element of culture that is analysed by most of the studies in relation to conflict solving is the dimension of individualism - collectivism, which is often regarded as the most important dimension underlying cultural differences. Many misunderstandings between Western and non-Western societies are attributed to this dimension (Ting-Toomey et al. 1991, Triandis 1989). The results mostly showed that individualistic cultures tend to use more obliging and dominated styles, while collectivistic countries tend to use more integrating and avoiding styles. 


\section{Research Methodology}

The research was conducted on the territory of Bosnia and Herzegovina, by surveying companies in which the founding capital is foreign, i.e. the organizational culture of the company is built on the principles of the national culture of the home country. As a tool for data collection, a structured questionnaire was used through which respondents, actually company managers, expressed views and opinions on conflict management in general, as well as personal experiences when it comes to interpersonal conflicts and their solving within the company in which they work. Moreover, knowledge of the national culture of the country in which the business is conducted for conflict management and the establishment of a positive work environment in the company.

For the purpose of the research, foreign companies that have internationalized their business in Bosnia and Herzegovina were selected. One of the criteria on the basis of which the sample was stratified is the ownership of capital, so for the purposes of this research, business entities that are in majority or full foreign ownership were selected. When it comes to the size of enterprises, it was taken into account that small, medium and large enterprises are included in the research, so this criterion was not limited when selecting a representative sample. However, it is important to emphasize that medium and large enterprises still predominate (17 large, 21 medium and 11 small enterprises).

Also, the scope of work was not a decisive factor for the selection of companies, the companies operating in various industries (manufacturing, construction, banking, wholesale and retail trade, IT sector, communications, etc.) were surveyed. The business entities in which the research was conducted were established in different countries, such as USA, Slovenia, Austria, Germany, Croatia, Great Britain, Romania, Turkey, Croatia, Italy, the Netherlands, Russia, etc.

For the questions, the method of choosing the answer that is closest to their views was used, as well as the five-point Likert scale, which made it easier for respondents to express their agreement or disagreement with the offered views and statements. The survey was conducted by direct contact with respondents and by email.

Based on the theoretical research, the main and supporting hypotheses were set, as follows:

- Main Hypothesis: Bosnia and Herzegovina's national culture has impact on conflict resolution styles.

- Supporting Hypothesis 1: Femininity, as dimension of national culture in Bosnia and Herzegovina, has impact on conflict resolution styles.

- Supporting Hypothesis 2: Collectivism, as dimensions of national culture in Bosnia and Herzegovina, has impact on conflict resolution styles. 
Since the research was conducted on the territory of $\mathrm{BiH}$, it was taken into consideration that companies have branches and operate in all parts of the country. Responses were received from a total of 49 managers from 49 companies where 20 respondents were men and 29 women. The majority of respondents in the sample are between 20-39 years old, actually $63 \%$ of them are between $30-39$ years old, while $27 \%$ of respondents are 20-29 years old,

When it comes to the level of education, most have a bachelor's or master's degree, a monthly level of incomes between 1200 and $2000 \mathrm{KM}$ (32 out of 49 respondents answered the question). Most of the respondents, more precisely $83.7 \%$ of them, have a contract for an indefinite period of time, while the largest number have been working for the company for 5 or more years. It is important to note that there is a small difference between the number of those who work from 1 to 5 or more than 5 years.

\section{Research Results}

\subsection{Changes, conflicts and conflict resolution in the organization}

First part of the empirical research collected opinions about general attitude towards the conflicts in companies, their causes, types and preferred resolution styles, followed by opinions about conflict management through Hofstede's cultural dimension while the third part collected opinions on importance of knowing the culture of host country and its impact on managerial practice and conflict resolution styles.

The literature confirm that conflicts could often come as a result of nervousness, dissatisfaction or inability to express disagreements within the company. Frequent changes within the company, too, can lead to conflicts, positive or negative. In the theoretical part, it is stated that the most common causes of conflict could be seen as organizational, personal or communicative. So, to the question "How often do you feel tense or nervous at work?" and most respondents answered with "sometimes" $(65 \%)$ or "mostly" $(25 \%)$. It is important to emphasize that none of the respondents answered "never", and only 3 respondents answered "rarely". Graph 4.2. shows how frequent conflicts are in the surveyed companies based on the opinions of managers in the company, who have been in these positions for 5 or more years. 
Graph 4.2: Frequency of conflict in the company

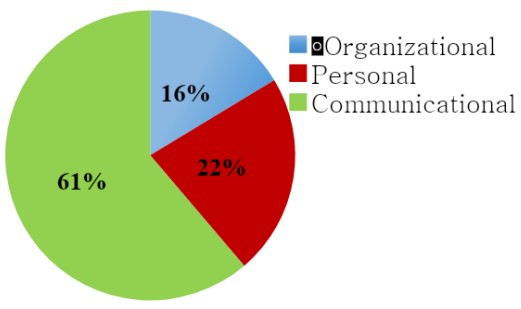

Graph 4.3: Main causes of workplace conflicts

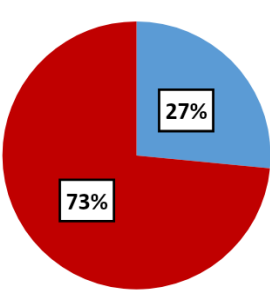

- Conflicts

exist and are frequent

Conflicts

- exist but are

not that

frequent

Conflicts do

not exist in

the company

Source: Author's work

Blue colour on the chart 4.2. shows the percentage of respondents who answered positively, i.e. that conflicts exist and are frequent (27\%). The red colour on the graph shows the percentage of respondents who answered negatively, i.e. that conflicts exist but are not frequent in the workplace (73\%). What is important to note is that none of the respondents answered "conflicts in the company do not exist". Although the previous chart shows that in $73 \%$ of surveyed companies conflicts are not frequent, they still exist. It is important to know why the conflict in the company arises and what causes them, as shown in Graph 4.3.

Then, the attitude of respondents to the conflict itself which can be viewed from the traditional basis where conflict is often considered extremely negative and undesirable or from a newer approach, where conflict can lead to new ideas and approaches was examined. The results show that 37 out of 49 respondents believe that conflicts are not always negative and can contribute to the improvement of business operations $(76 \%)$. Therefore, a more modern attitude within the companies prevail, where conflict is seen as a normal and inevitable phenomenon that can lead to new ideas and approaches.

The results of the respondents' answers to the question about the preferred conflict resolution style are shown in Graph 4.5.

Graph 4.5: Best conflict resolution strategy

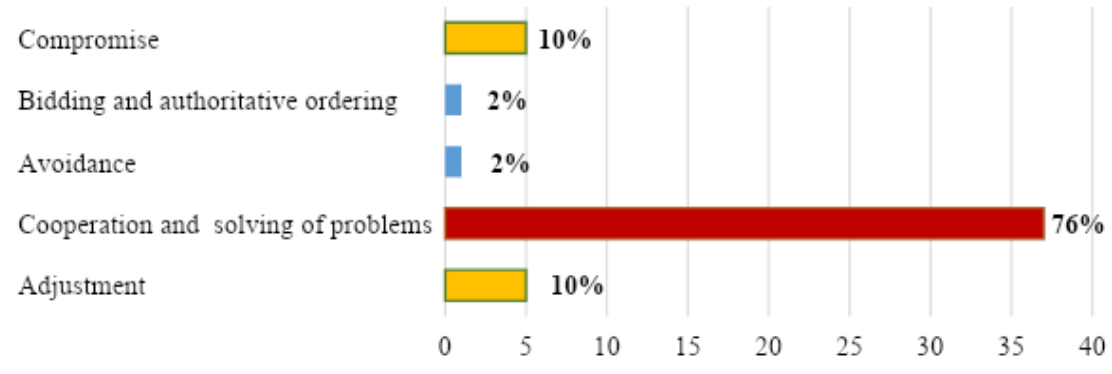

Source: Author's work 
The results show that $76 \%$ of respondents believe that cooperation and solving of problems is the best strategy for resolving conflicts, and only $2 \%$ of them chose bidding and authoritative ordering as well as avoidance as the best strategy. Through the theoretical part of the paper, cooperation has been recognized as one of the best ways to manage conflict, and this has been confirmed by empirical research. Compromise and adjustment is considered by an equal number of respondents $(10 \%)$ to be the best conflict resolution strategy.

\subsection{Examining the preferences of conflict management according to Hofstede's dimensions of national culture}

When asked to assess how much they agree with the statement "Conflicts are resolved by involving and obeying superiors", $46.9 \%$ agreed and $18.4 \%$ strongly agreed. This is in accordance with high power distance as identified cultural dimension for Bosnia and Herzegovina, as well as with collectivism. Majority of respondents also try to fulfil the expectations of their superior, yet the smaller percentage behave the same with their co-workers while managing conflicts, as shown in graphs 4.6. and 4.

Graph 4.6: In my work, I try to fulfil the expectations of my superiors

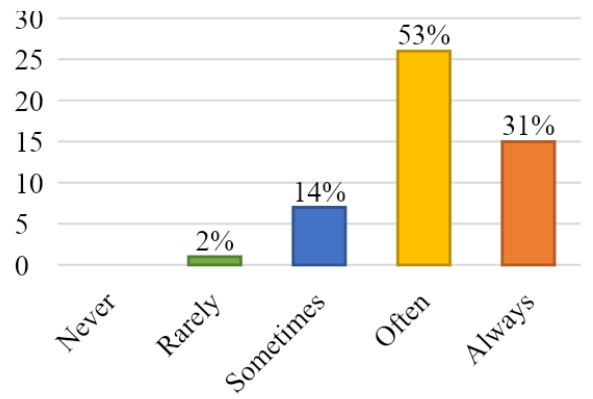

Graph 4.7: I try to fulfil the expectations of my co-workers

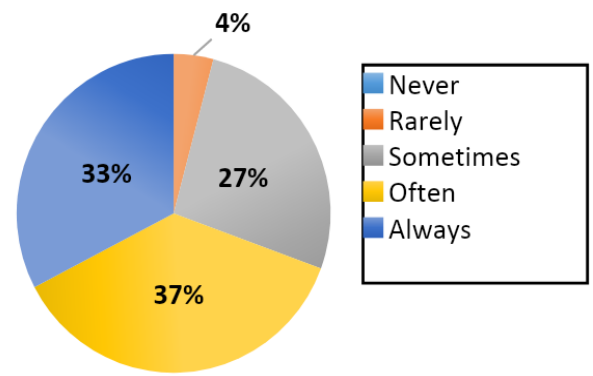

Source: Author's work

Respondents were also asked to imagine an ideal job, regardless of their current job, where they stated, among other things, that it is important and very important for them to have good relations with their direct superior and to have security at work (Graph 4.8), which can be linked to uncertainty avoidance and power distance dimensions of culture. 
Graph 4.8: Good relations with direct superiors and security at work

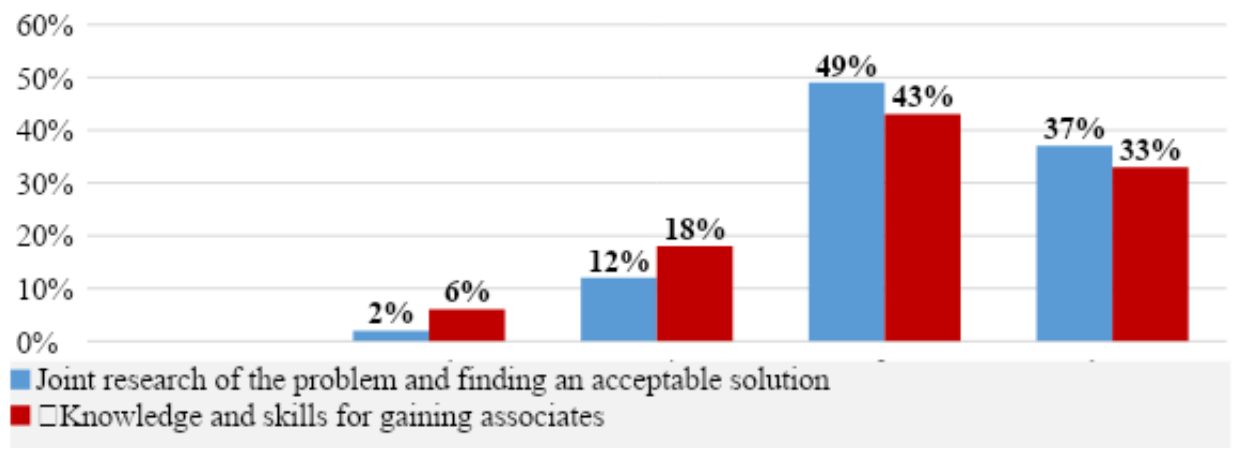

Source: Author's work

The chart below shows opinions on the statements "In my work, I try to investigate the problem and cooperate with my superiors / colleagues to find a solution that is acceptable to all", and" I use my knowledge and skills to gain associates", where through the proper use of knowledge, skills and abilities, one can build positive relationships in the company.

Graph 4.9: Good relations in the company

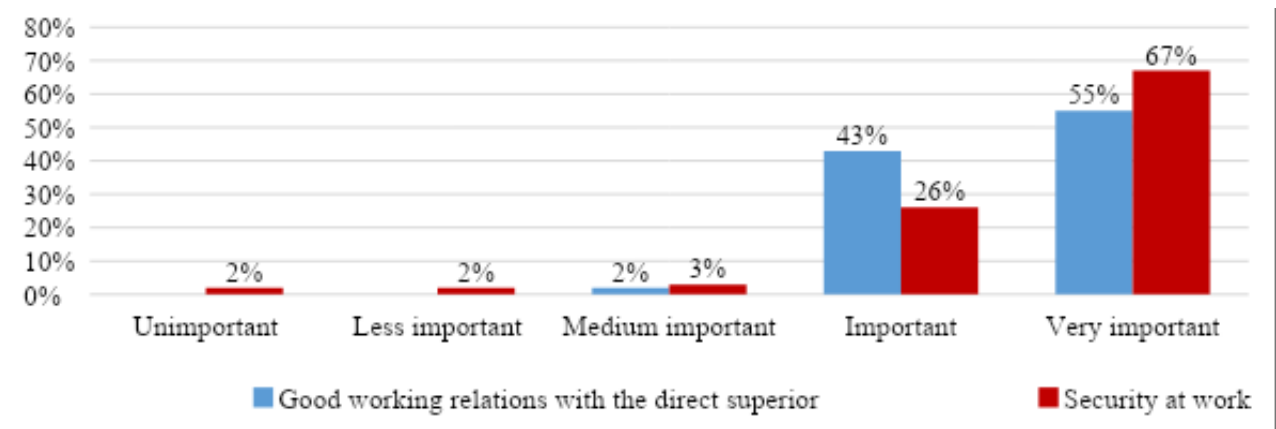

Source: Author's work

Most respondents stated that cooperation and finding a solution acceptable for everyone is very important, as well as collective responsibility and good relationships with other group members, which is in accordance with collectivistic cultures. This is additionally confirmed by answers to the question "I exchange accurate information with my colleagues to solve the problem together", where most of the respondents answered with "often" or "always", as presented in Graph 4.10. 
Graph 4.10: Teamwork and good relations in the company

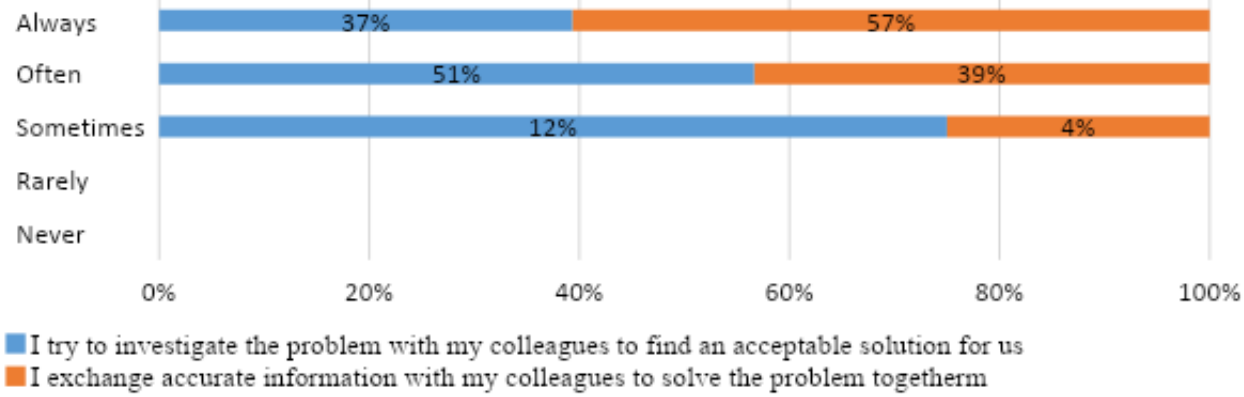

Source: Author's work

Most of the respondents stated that they use negotiation and compromise as strategies for conflict management, as well as open communication, as shown in Graph 4.11.

Graph 4.11: Open communication and compromise in the company

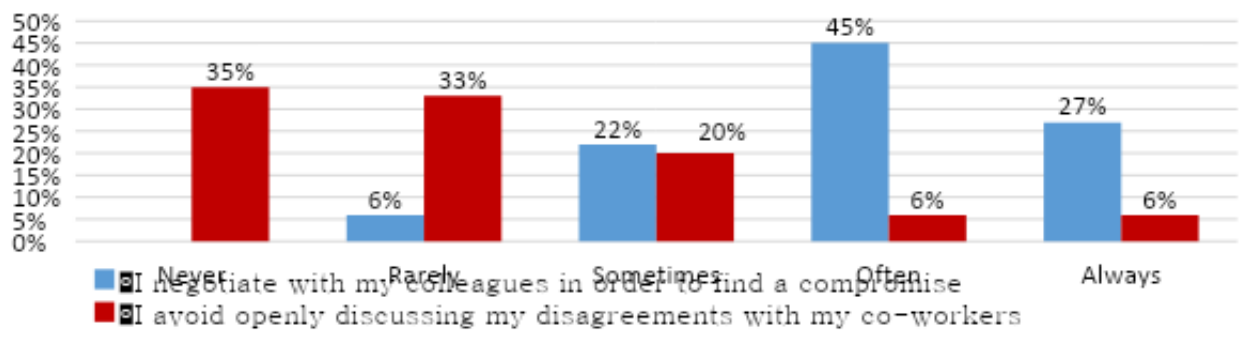

Source: Author's work

The results are in accordance with collectivistic cultures as well as cultures with predominant femininity values, which are characterized by a positive result through cooperation, compromise and joint work and commitment.

\subsection{Examining the relationship between cultures of home and host countries}

As mentioned before, good communication and cultural knowledge helps in conflict prevention as well as resolution. Therefore, respondents were offered a statement on "The knowledge of the customs, traditions and cultural heritage of the country in which the business operates or from which associates come contributes to better communication and more successful business." The answers are presented in the following chart. 
Graph 4.12: Customs, traditions and cultural heritage of the country

The knowledge of the customs, traditions and cultural heritage of the country in which the business operates or from which associates come contributes to better communication and more successful business

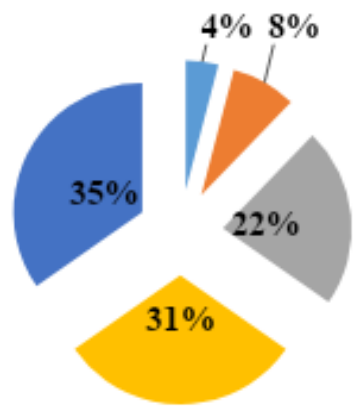

\author{
Strongly disagree \\ Disagree \\ Neither agree nor disagree \\ Agree \\ Strongly agree
}

\section{Source: Author's work}

The statements "I agree" and "I completely agree" was chosen by $66 \%$ of respondents, indicating that knowledge about host country culture is seen as very important in general. Then, the respondents were asked to assess the importance of knowledge of national culture as well as the consistency of managerial practice in accordance with the cultural assumptions and values of the host country for conflict management and the establishment of good managerial practice. The majority of respondents $(90 \%)$ stated that it is important to know the national culture and that it is important that managerial practice is consistent in accordance with the cultural assumptions and values of the country in which it operates.

Then, respondents were asked to make a comparison between the conflict resolution styles applied in home country and in Bosnia and Herzegovina, as host country. The results are presented in Graph 4.13.

Graph 4.13: Interpersonal conflict management system

Is the same conflict management system applied in the representative office / headquarters of the company in $\mathrm{BiH}$ as in the parent company abroad?

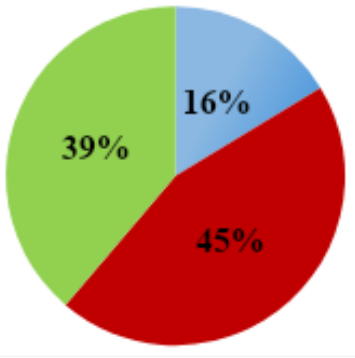

Yes, the same interpersonal conflict

management system applies

-The interpersonal conflict

management system is similar

-No, the same interpersonal conflict

management system does not apply

Source: Author's work 
Only $16 \%$ of respondents answered that the same conflict management style is used in both, home and host country, while majority of respondents (45\%) use similar style. The results could be explained by possible similarities between cultures of home and host countries and therefore similar preferred conflict resolution styles.

Graph 4.15. presents results of questions about competition between employees as well as about importance of relationship over tasks in the companies.

Graph 4.15: Relations and competition between employees in the company

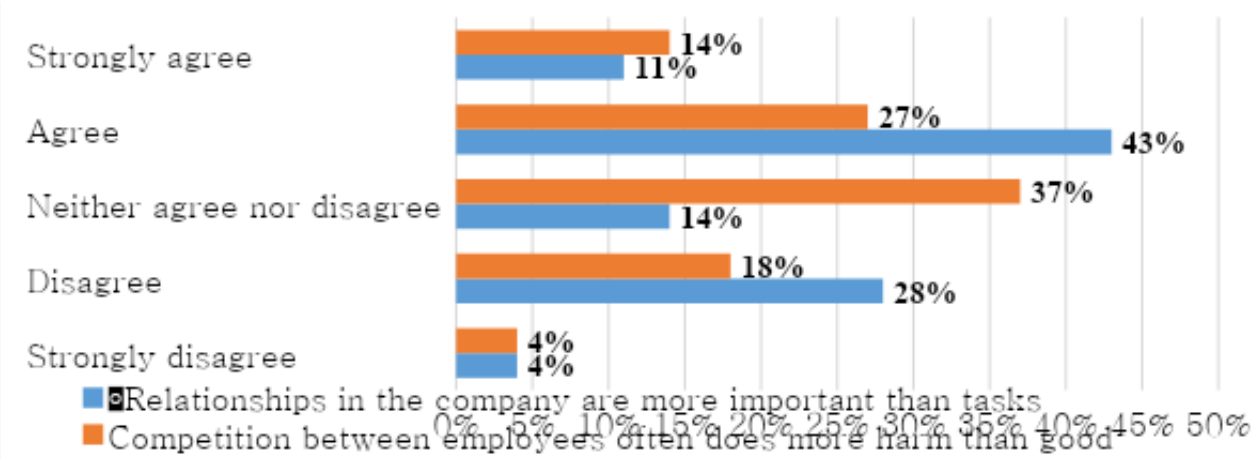

Source: Author's work

Results show that although $41 \%$ of respondents (14\% - strongly agree, $27 \%$ - agree) stated that competition between employees often does more harm than good, there is still a large number of respondents, who are indecisive (37\%). On the other hand, $54 \%$ of respondents "agree" or "strongly agree" with the statement that "Relations in the company are more important than tasks". Therefore, the results indicate that cooperation and good relationships among the member of group are more important than competition and tasks. These results are in accordance with both collectivistic cultures as well as one with predominate feminine values. Also, it could be said that if the relations in the company are positive and the transfer of information is real, it is much easier for tasks to be performed accurately, on time and to lead to the realization of business performance of the company.

\section{Interpretation of Results}

The study was conducted aiming to determine impact of Bosnian and Herzegovinian national culture on conflict resolution styles applied in companies with foreign capital/owners doing business in Bosnia and Herzegovina.

The results of a research show that conflicts do exist in companies, even though they are not that frequent. As already stated, the main causes of conflicts in the workplace are organizational, personal, and communicational. As most conflicts arise from too 
little or too much communication, then it is not surprising that the largest number of respondents emphasized that the most common conflicts in their companies are communicational.

Since the research was conducted in companies with foreign capital/owners, it was important to determine their attitude towards the importance of knowing the culture where their business was internationalized. The results show that it is very important to know the national culture of the host country in which the business is conducted. Furthermore, they also show that it is very important that managerial practice is in accordance with the cultural assumptions and values of the host country. This implies that, even though the core values and principles of company are preserved regardless of location, adjusting to the host country culture is imperative for establishing successful business operation. In regard to conflict resolution styles used in these companies in their home country and in Bosnia and Herzegovina, results show that the similar or the same conflict resolution style is used. The results could be explained by possible similarities between cultures of home and host countries and therefore similar preferred conflict resolution styles as well as perceived importance of adjusting managerial practice to the host country.

The results show that preferred conflict resolution styles applied in companies are based on cooperation and finding solution acceptable to all, while competition is not perceived as suitable behaviour. Additionally, another important conflict resolution style is based on involving and obeying superiors. Therefore, it could be argued that two basic conflict resolution styles are present in companies, one based on cooperating with peers in finding a resolution that all could be satisfied with and other, based on authority of a superiors in a companies. Both of these conflict resolution styles could be found in Rahim's Dual concern model, where they could be linked to the integrating style and the obliging style. Both of these styles have concern for others in their foundation.

Moreover, the preferred conflict resolutions styles could be easily explained by Hofstede's cultural dimensions which are dominant in Bosnia and Herzegovina. Concern for others is in the core of collectivism, as well as teamwork, team rewards, and good relationships with co-workers. Therefore, competing with co-workers and insisting on individual interests are not seen as acceptable behaviour, while cooperating and finding common solutions are. Involving and obeying superiors as a conflict resolution style is also typical for collectivistic cultures, which prefer involving the third party (superiors) in resolving the conflict. Additionally, this style of conflict resolution is in accordance with high power distance cultures, where hierarchical structure is known and respected. Obeying a superior who, based on his position in a company, is seen as more powerful by other employees is a given. 
Furthermore, the results of conflict resolution styles could be linked to feminine values, as yet another Hofstede's cultural dimension present in Bosnia and Herzegovina. The results showed that employees perceive relationships more important than tasks in companies, equality and solidarity are highly valued, so friendly relations among all colleagues, as well as cooperation and joint finding of solutions if there is a problem or a conflict will positively affect relations in the company. These all are characteristics of the dimension of femininity and is something that should be nurtured in companies. Therefore, the results are in accordance with cultures with predominate femininity values, which are characterized by a positive result through cooperation, compromise and joint work and commitment.

Hence, the empirical research results show that conflict resolution styles applied in+ companies with foreign capital/owner doing business in Bosnia and Herzegovina are in accordance with several Hofstede's dimensions of culture, namely: collectivism, high power distance and femininity. Therefore, it could be stated that femininity and collectivism, as as dimension of national culture in Bosnia and Herzegovina, have impact on conflict resolution styles, which confirms main assumptions leading this research.

\section{CONCLUSION}

Business today is increasingly impacted by international considerations. Managers need to be aware of the culturally derived social customs and the specific behaviours of people in the different countries involved. Even if a business operates solely in a single country, chances are good that its employees will come from different countries, due to the increasing immigration. Again, an awareness of and sensitivity to the differing modus operandi of businesses and people around the world is imperative. Perhaps, nowhere is this awareness more necessary than in the area of conflict management. If conflict is managed in a proper manner, by taking into account all the different cultures, organizations should become more efficient.

The purpose of this study was to explore and describe relation between culture and conflict resolution styles in companies with foreign capital/owners doing business in Bosnia and Herzegovina. Main aim was to determine the impact of Bosnia and Herzegovina's national culture on applied conflict resolution styles. In the research, the construct of culture was operationalized by two cultural dimensions, namely collectivism and femininity. In order to determine the impact of culture of Bosnia and Herzegovina on conflict resolution styles, theoretical an empirical research was conducted. Based on literature review of conflict resolution styles, general conclusion could be that culture has significant impact on conflict resolution styles. Empirical research supports that conclusion as well, since the results clearly show the 
link between collectivism and feminine values, as cultural dimensions, on preferred conflict resolution styles.

The study is not without limitations. Further enquiries should be done on a broader sample of companies with more detailed questionnaires taking into account the other cultural dimensions as well. Having that stated, the conducted study has its contributions, both in theory and managerial practise. The results of the research can be used as a good basis for further research, but they can also be used by managers of the companies internationalizing their business abroad. Knowing the customs, traditions and cultural heritage of team members (owners, managers, employees, colleagues), but also the national culture of the country is extremely important for establishing positive values and managerial practices that could lead to business success.

\section{REFERENCES}

1. Akerlof, G. A., Kranton, R., E. (2012), Ekonomija identiteta - Kako naši identiteti oblikuju naš rad, plaće i blagostanje, MATE, Zagreb

2. Barringer, B. R., Ireland, R. D. (2010), Poduzetništvo - uspješno pokretanje novih poduhvata, Prentice Hall, Tuzla

3. Berry, J. W., Poortinga, Y. H., Pandey, J. (1997), Handbook of Cross-cultural Psychology. Social Behavior and Aplications, Allyn\&Bacon, Massachusetts, USA.

4. Black, R. J. (2003), Organisational Culture: Creating the Influence Needed for Strategic Success, London

5. Brooks, I. (2006), Organisational Behaviour: Individuals, Groups and Organisation (3rd Edition), Prentice Hall/Financial Times

6. Browaeys, M. J., Price, R. (2008), Understanding Cross-Cultural Management, Pearson Education, London

7. Buble, M. (2010), Utjecaj organizacijskih varijabli na uspjeh programa unapređenje poslovnih procesa, Ekonomski fakultet Split, Split

8. Chapman, E. N., O’Neil, S. N., Gabrić, A. (2003), Vodstvo - Osnovni koraci koji svaki menadžer treba znati, MATE, Zagreb

9. Cox, T. (2004), Stvaranje multikulturalne organizacije, MATE, Zagreb

10. Dedić, M., Umihanić, B. (2004), Osnove menadžmenta i poduzetništva, Ekonomski institut Tuzla, Tuzla 
11. Dunning, J. (1992), Multinational enterprises and the global economy, Addison-Wesley Publishing Company, Boston

12. Đorđević, M. (2008), Strategije internacionalizacije preduzeća u novom poslovnom okruženju, Ekonomski fakultet, Kragujevac

13. Elsayed-Ekhouly, S. M. and Buda, R. (1996), "Organizational Conflict: A Comparative Analysis of Conflict Styles Across Cultures", The International Journal of Conflict Management, Vol 7 No 1, pp 71-81.

14. Gerhart, B. (2009), Does National Culture Constrain Organization Culture and Human Resource Strategy? The Role of Individual Mechanisms and Implications for Employee Selection, University of Wisconsin-Madison

15. Glen, E. S. (1981), Man and Mankind: Conflict and Communication between Cultures, Ablex, Norwood, NJ

16. Griffin, E. (1997), A First Look at Communication Theory, McGraw Hill, New York

17. Hall, E. T. (1976), Beyond culture, Doubleday, New York

18. Hofstede, G. (1984), Culture's Consequences: International Differences in Work-Related Values, Volume 5 of Cross Cultural Research and Methodology, SAGE Publications, California

19. Hofstede, G. H. (2001), Culture's Consequences: Comparing Values, Behaviors, Institutions and Organizations Across Nations, Sage Publications, California

20. Hofstede, G., Hofstede, G. J., Minkov, M. (2010), Cultures and Organizations. Software of the Mind, McGraw-Hill, USA

21. Jameson, F., Miyoshi, M. (1998), The Cultures of Globalization, Duke University Press, Durham and London

22. Johnston, H. J. (2008), International Leadership in Cross-cultural Environments: The Relationship Between National Culture and Corporate Culture as it Pertains to Work Ethic and Corporations, ProQuest Information and Learning Company

23. Kozan M. K. (2002), Subcultures and Conflict Management Style, Management International Review, Vol 42, No 1

24. Kozan, M. K. (1989), "Cultural Influences on Styles of Handling Interpersonal Conflict: Comparison among Jordanian, Turkish and US managers", Human Relations, No 42, pp 787-799 
25. Kozan, M. K. (1989), Cultural Influences on Styles of Handling Interpersonal Conflict: Comparasion among Jordanian, Turkish and US managers, Human Relations, No 42

26. Minkov, M. (2011): Cultural Differences in a Globalizing World, Bigley: Emerald Group Publishing Ltd.

27. Nicholson M. B. (1975), "The Resolution of Conflict", in Young, OR (Ed.), "Bargaining", University of Illinois Press, Chicago, IL, pp 231 - 242.

28. Nicholson, M. B. (1975), The Resolution of Conflict, University of Illinois Press, IL

29. Podrug, N., Pavičić, J., Bratić, V. (2011), Cross-Cultural Comparison of Hofstede's Dimensions and Decision-Making Style within Cee Context, Ekonomski fakultet Zagreb, Zagreb

30. Rahim, M. A. (1983), "A Measure of Styles of Handling Interpersonal Conflict" Academy of Management Journal, Vol 26 No 2, pp 368 - 76.

31. Rahim, M. A., (2001), Managing Conflict in Organizations, $3^{\text {rd }}$ Edition, Westport, CT, London

32. Rahimić, Z. (2010), Menadžment ljudskih resursa, Ekonomski fakultet u Sarajevu, Sarajevo

33. Rakita, B., (2006), Međunarodni biznis i menadžment, Centar za izdavački djelatnost Ekonomskog fakulteta u Beograd, Beograd

34. Robbins, P. S. (1995), Bitni elementi organizacijskog ponašanja, MATE d.o.o., Zagreb

35. Robbins, S. (2005), Essentials of Organizational Behavior, VIII ed., Pearson Prentice Hall, Upper Saddle River, New Jersey

36. Thompson, K. R., Luthans, F. (1990), Organizational culture: A behavioral perspective, Jossey-Bass, San Francisco

37. Tinsley, C. H. and Brett, J. M. (2001), "Managing Workplace Conflict in the United States and Hong Kong", Organizational Behavior and Human Decision Process, Vol 85 No 2, pp. $350-81$. 
Dijana Husaković

Anida Šabanović

\section{UTJECAJ BOSANSKOHERCEGOVAČKE NACIONALNE KULTURE NA STILOVE RJE ŠAVANJA KONFLIKATA U STRANIM PREDUZEĆIMA}

\section{SAŽETAK}

Konflikti su sastvani dio poslovanja preduzeća i preduzeća ih ne mogu izbjeći. U globaliziranom i dinamičnom okruženju, javlja se potreba upravljanja konfliktima, kad se pojave u preduzeću, na produktivan i efektivan način. Stilovi rješavanja konflikata su pod utjecajem različitih faktora, uključujući i nacionalnu kulturu zaposlenika, koji će u skladu sa svojom kulturom, imati određene preferencije u rješavanju konflikata.

Kada se govori o kroskulturalnom okruženju, poznavanje nacionalne kulture zemlje domaćina, ali i poznavanje nacionalne kulture domaće zemlje je veoma važno za upravljanje konfliktima i kreiranje pozitivne radne atmosfere u preduzécu. Poslovanje na stranim tržištima dodatno usložnjava proces nastanak konflikata u preduzeću. Iz tih razloga, menadžeri koji dolaze u državu domaćina iz strane države imaju važan zadatak razumijevanja vlastitih vrijednosti i običaja ali $i$ vrijednosti i običaja drugih kultura, odnosno kultura drugih država u koje je preduzeće internacionaliziralo svoje poslovanje.

Cilj rada je da, na osnovu provedenog teorijskog i empirijskog istraživanja, da odgovor na pitanje utjecaja bh. nacionalne kulture na stilove rješavanja konflikata u stranim preduzećima koja posluju u Bosni i Hercegovini.

Rezultati istraživanja pokazuju da je nacionalna kultura signifikantan faktor u upravljanju konfliktima u preduzeću, te da zaposlenici u Bosni i Hercegovini preferiraju stilove rješavanja konflikata u skladu sa vlastitim kulturološkim vrijednostima $i$ običajima. Nivo harmonizacije stilova rješavanja konflikata u stranim preduzećima koja posluju u Bosni i Hercegovini, odnosno njihovo prilagođavanje kulturološkim vrijednostima zemlje domaćina može imati utjecaj na poslovanje preduzeća, kreiranje produktivne radne atmosfere i ostvarivanje postavljenih ciljeva.

Ključne riječi: kultura, konflikt, stilovi rješavanja konflikata

JEL: $M 14, M 54, F 23$ 